\title{
Hydration regulates thermodynamics of G-quadruplex formation under molecular crowding conditions
}

Daisuke Miyoshi, Hisae Karimata, Naoki Sugimoto

\section{Page 1: contents}

Page 2: Figure S1 for $\mathrm{CD}$ spectra and native gel electrophoresis of the antiparallel G-quadruplex and HP duplex in the presence of $\mathrm{K}^{+} \mathrm{or} \mathrm{Na}^{+}$with or without $40 \mathrm{wt} \%$ PEG 200) Page 3: Figure S2 for thermal denaturation and renaturation curves of the antiparallel G-quadruplex in the presence of $\mathrm{K}^{+}$or $\mathrm{Na}^{+}$with or without $40 \mathrm{wt} \%$ PEG 200)

Page 4: $\quad$ Figure S3 for normalized UV melting curves for the G-quadruplex and HP duplex in the presence of $\mathrm{Na}^{+}$at various concentrations of PEG 200) 

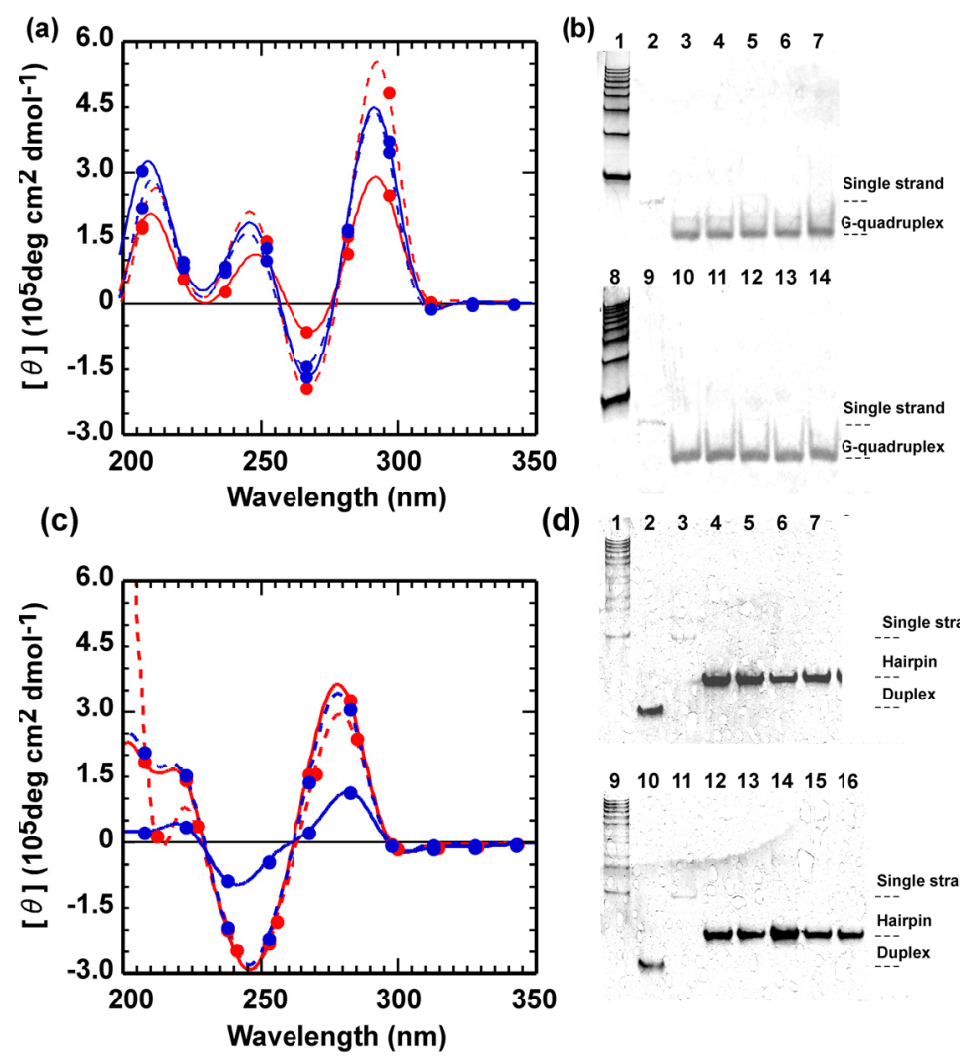

d) $\begin{array}{lllllll}1 & 2 & 3 & 4 & 5 & 6 & 7\end{array}$
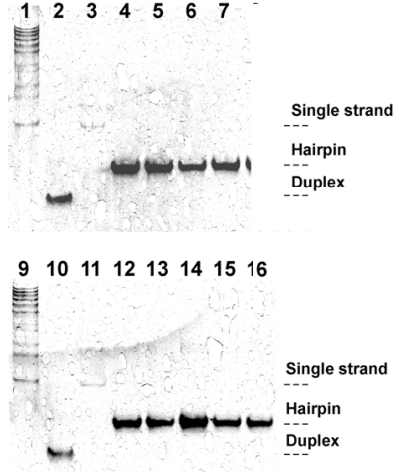

Figure S1. (a) CD spectra of $50 \mu \mathrm{M}$ G-quadruplex in buffers containing $100 \mathrm{mM} \mathrm{KCl}, 10 \mathrm{mM} \mathrm{K}_{2} \mathrm{HPO}_{4}$ (pH 7.0), and $1 \mathrm{mM} \mathrm{K}{ }_{2}$ EDTA (blue) or $100 \mathrm{mM} \mathrm{NaCl}, 10 \mathrm{mM} \mathrm{Na}_{2} \mathrm{HPO}_{4}$ (pH 7.0), 1 mM Na 2 EDTA (red) with (dotted line) or without $40 \mathrm{wt} \%$ PEG 200 (solid line) at $4^{\circ} \mathrm{C}$. (b) Native gel electrophoresis of the G-quadruplex on a $20 \%$ polyacrylamide gel in the following buffers: $100 \mathrm{mM} \mathrm{KCl}, 10 \mathrm{mM} \mathrm{K} \mathrm{HPO}_{4}(\mathrm{pH}$ 7.0), and $1 \mathrm{mM} \mathrm{K} \mathrm{E}_{2} \mathrm{EDTA}$ (upper) or $100 \mathrm{mM} \mathrm{NaCl}, 10 \mathrm{mM} \mathrm{Na}_{2} \mathrm{HPO}_{4}$ (pH 7.0), and $1 \mathrm{mM} \mathrm{Na} \mathrm{EDTA}$ (lower) with 0 (lanes 3 and 10), 10 (lanes 4 and 11), 20 (lanes 5 and 12), 30 (lanes 6 and 13), or $40 \mathrm{wt} \%$ (lanes 7 and 14) of PEG 200 at $4^{\circ} \mathrm{C}$. Lanes 1 and 9 contained a 10-bp DNA ladder. Lanes 2 and 9 contained a single-stranded 15-mer DNA marker. (c) CD spectra of $50 \mu \mathrm{M}$ HP duplex in buffers containing $100 \mathrm{mM} \mathrm{KCl}$ (blue) or $\mathrm{NaCl}$ (red), $10 \mathrm{mM} \mathrm{Na}_{2} \mathrm{HPO}_{4}$ (pH 7.0) 1 mM Na $2 \mathrm{EDTA}$ (pH 7.0), with $40 \mathrm{wt} \%$ PEG 200 (dotted line) or without PEG 200 (solid line) at $4^{\circ} \mathrm{C}$. (d) Native gel electrophoresis of the HP duplex on $20 \%$ polyacrylamide gel in the buffers containing $100 \mathrm{mM} \mathrm{KCl}, 10 \mathrm{mM} \mathrm{K}_{2} \mathrm{HPO}_{4}(\mathrm{pH}$ 7.0) $1 \mathrm{mM} \mathrm{K}{ }_{2}$ EDTA (pH 7.0) (upper) or NaCl, $10 \mathrm{mM} \mathrm{Na}_{2} \mathrm{HPO}_{4}$ (pH 7.0) $1 \mathrm{mM} \mathrm{Na} 2 \mathrm{EDTA}$ (pH 7.0) (lower), with $0 \mathrm{wt} \%$ (lanes 4 and 12), $10 \mathrm{wt} \%$ (lanes 5 and 13), $20 \mathrm{wt} \%$ (lanes 6 and 14), $30 \mathrm{wt} \%$ (lanes 7 and 15), or 40 wt \% (lanes 8 and 16) PEG 200 at $4^{\circ} \mathrm{C}$. Lanes 1 and 9 are 10 base pair DNA ladder. Lanes 2 and 10 are 12 mer duplex DNA markers. Lanes 3 and 11 are single-stranded 28 mer DNA marker. 

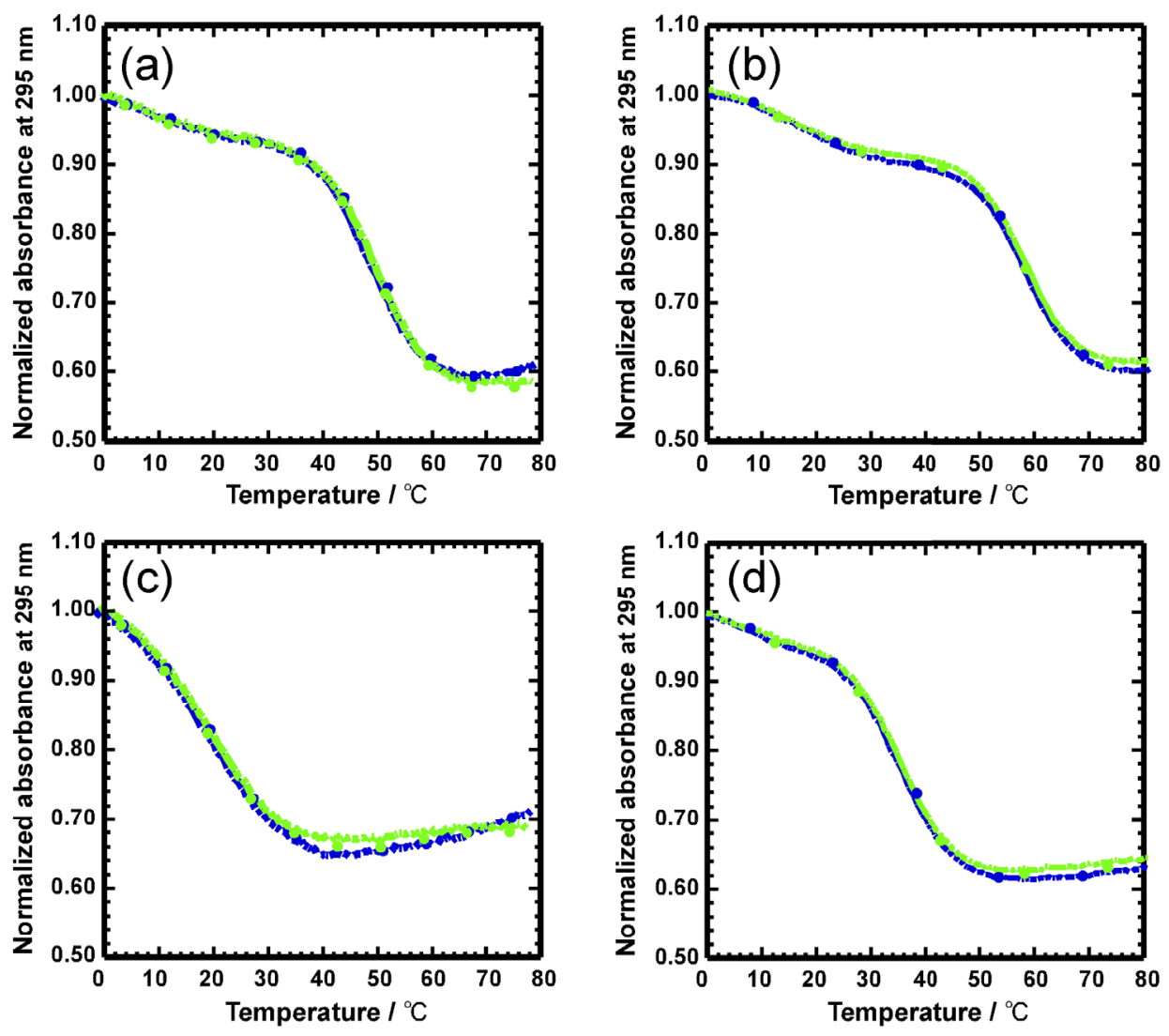

Figure S2. Thermal denaturation (blue) and renaturation (green) curves of $5 \mu \mathrm{M}$ G-quadruplex in buffers containing $100 \mathrm{mM} \mathrm{KCl}, 10 \mathrm{mM} \mathrm{K}_{2} \mathrm{HPO}_{4}\left(\mathrm{pH} 7.0\right.$ ), $1 \mathrm{mM} \mathrm{K} \mathrm{EDTA}_{2}$ (a), $100 \mathrm{mM} \mathrm{KCl}, 10 \mathrm{mM} \mathrm{K} \mathrm{HPO}_{4}$ (pH 7.0), $1 \mathrm{mM} \mathrm{K}_{2}$ EDTA with 40 wt \% PEG 200 (b), $100 \mathrm{mM} \mathrm{NaCl}, 10 \mathrm{mM} \mathrm{Na}{ }_{2} \mathrm{HPO}_{4}$ (pH 7.0), 1 mM Na 2 EDTA (c), or $100 \mathrm{mM} \mathrm{NaCl}, 10 \mathrm{mM} \mathrm{Na}_{2} \mathrm{HPO}_{4}$ (pH 7.0), 1 mM Na 2 EDTA with 40 wt \% PEG 200 (d). The curves were traced with UV absorbance at $295 \mathrm{~nm}$. 
(a)

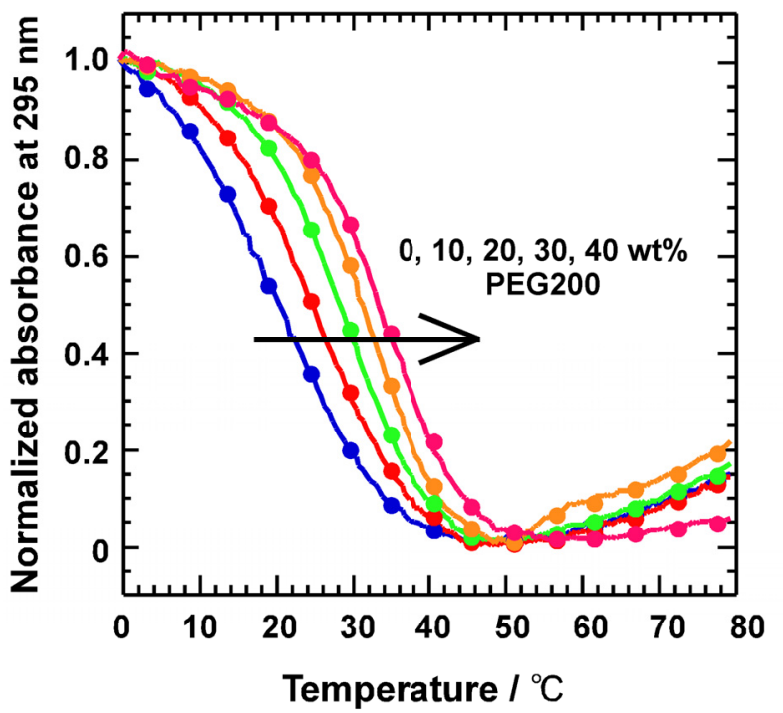

(b)

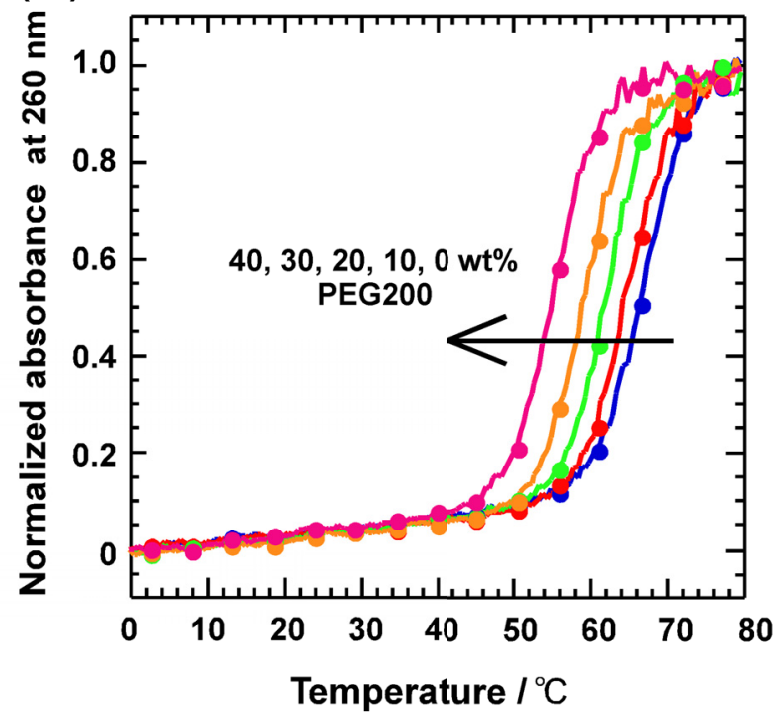

Figure S3. (a) Normalized UV melting curves for $5 \mu \mathrm{M}$ G-quadruplex and (b) normalized UV melting curves for $5 \mu \mathrm{M}$ HP duplex in buffers of $100 \mathrm{mM} \mathrm{NaCl}, 10 \mathrm{mM} \mathrm{Na}_{2} \mathrm{HPO}_{4}$ (pH 7.0), and $1 \mathrm{mM} \mathrm{Na}_{2}$ EDTA containing 0 $\mathrm{wt} \%$ (blue), $10 \mathrm{wt} \%$ (red), $20 \mathrm{wt} \%$ (green), $30 \mathrm{wt} \%$ (orange), or $40 \mathrm{wt} \%$ (pink) PEG200. 